\title{
20. Yüzyılda Sanatsal Takının Gelişim Sürecinde Heykel Sanatının Etkisi
}

\author{
Neşem ERTAN AYATA *
}

Özet

20. yüzyılda batılı toplumlarda yaşanan olağanüstü gelişmeler ve yansımaları, tüm dünyada kültürel yapının değişmesine neden olmuştur. Söz konusu değişim dönemin sanat yapısını etkilemiş, 20. yüzyılın özellikle ikinci yarısında, alışılagelmiş takı algısının kalıplarının kırılmasına yol açmıştır. Takı olgusunun geçirdiği dönüşümle birlikte sanatsal takı kavramının ortaya çıkışı, bu döneme rastlar. Bu çalışmada, 20. yüzyılda takının sanatsal bir ifade biçimine dönüşme süreci, takı anlayışında geleneğin aşııması ve heykel sanatının takı sanatına etkileriyle takının heykelsileşmesi üzerine yapılan araştırmanın sunulması amaçlanmaktadır.

Anahtar Sözcükler: Sanatsal Takı, 20. Yüzyılda Takı, Heykelsi Takı, Sanat Olarak Takı.

\section{Influence of the Art of Sculpture on Development Process of Artistic Jewellery in the 20th Century}

Abstract

In the 20th century, extraordinary developments and their reflections in Western societies have caused the evolution of cultural structure worldwide. This evolution influenced the period's artistic atmosphere and especially in the second half of the 20th century, this has caused the breaking of the conventional modes of jewellery. The emergence of conception of artistic jewellery along with the transformation of jewellery as a fact coincides with this period. This paper aims to present the transformation period of jewellery into an artistic mode in the 20th century; going beyond the traditions in the jewellery concepts and the influence of sculpture as an art form on the art of jewellery.

Keywords: Artistic Jewellery, 20th Century Jewellery, Sculptural Jewellery, Jewellery as an Art Form. 


\section{Giriş}

Klasik anlamda takı ve mücevher, kendisine atfedilen değerli malzemelerle ve önceden tariflenmiş formlarda üretilmekte iken, 20. yüzyılın başından itibaren tüm dünya kültüründe yaşanan gelişmeler, takı anlayışının da dönüşümüne sebep olmuştur. Sanayi Devriminden dünya savaşlarına, sosyal devrimlerden bilim ve teknolojinin gelişmesine, olağanüstü hızlı bir değişimden geçildiği bu dönemde; sanat anlayışı da büyük kırılmalar yaşamış ve büyük bir etki alanı yaratmıştır.

20. yüzyılda kültür ve sanat alanında yaşanan gelişmeler, pek çok sanat dalında olduğu gibi, çağdaş takı, heykel ve diğer üç boyutlu sanat formlarını birlikte şekillendirmiş; özellikle takıyı geri dönülmez biçimde değiştirmiştir. Bu yüzyılın ilk yarısına damgasını vuran biçimsel kaygılar, günümüz sanatını da etkilemiştir (Lewin, 1994: 59).

Amerika'da sanat oluşumu, İkinci Dünya Savaşı nedeniyle Avrupa'dan Amerika'ya göç ederek Bauhaus etkilerini ülkelerine taşıyan yüzlerce sanatçı ve kuyumcunun etkisi altında kalmıştır. Tasarım eğitimini de etkileyen Walter Gropius, Mies Van Der Rohe, Laszlo Moholy-Nagy gibi sanatçılar, kendilerinden sonra gelecek nesli yönlendirmiş ve Bauhaus ekolünün yaygınlaşmasında önemli rol oynamışlardır. “Bauhaus’un tüm geleneksel sınırlamaları kırma ideolojisi, ABD’de bereketli topraklar bulmuştur." (Scarisbrick vd., 1989: 151).

Sanat, 1940 'lar ve 50'lerde Amerikan Soyut Ekspresyonistlerin etkisinde kalmıştır. Sanatçılar, kendilerini gelenekten bağımsız öncüler olarak nitelendirmişlerdir. Bu fikir, tasarım ve sanat dünyasında hızla yaygınlaşmıştır. Bu dönemde Studio Crafts (Stüdyo Zanaatları) kavramı önem kazanır. Tek bir kişinin el yapımı olan bir ürünün hem tasarımından hem de üretiminden sorumlu olmasına işaret eden kavram, başta Amerika, Avustralya ve Ingiltere olmak üzere pek çok ülkenin sanat okullarında yer bulur (Scarisbrick vd., 1989:165). Bu gelişme takıya, ifadeci bir sanat formu olarak yeni bir rol kazandırır (Scarisbrick vd.,
1989: 165). Stüdyo zanaatkarlarının eğitiminden geçen yeni nesil tasarımcılar, takı kavramını değiştirirler. Takıda başlattıkları modernist form, heykelsi kimlik ve alternatif malzemelerin kullanımıyla geleneğe meydan okurlar (Astfalck vd., 2005: 19).

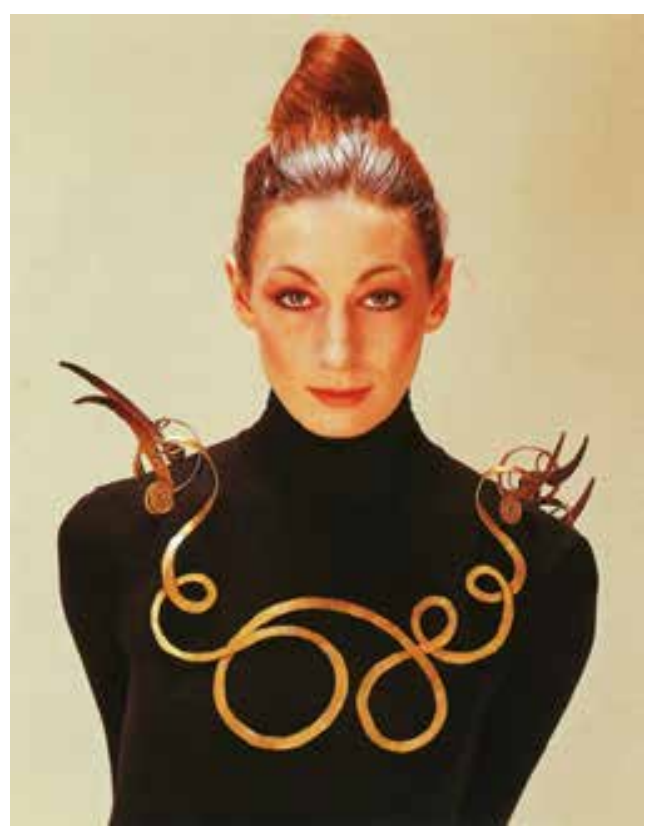

Resim 1. Alexander Calder, 'The Jealous Husband', pirinç kolye.

1960'lardan itibaren ortaya çıkan Pop Art ve Minimalizm gibi sanat akımları, kaçınılmaz olarak deneysel takı yapan tasarımcıları da etkilemiş ve bu akımlar, çağdaş takı çalışmalarında da karşılık bulmuştur (Lewin, 1994: 59). 1960'larda sanatsal yaklaşım çok daha öteye taşınmış, Bauhaus teorileri tüm Avrupa'daki sanat eğitimi veren kurumların ve tasarımcıların çoğuna ilham kaynağı olmaya devam etmiştir. Evrensel, rasyonel, yalın ve minimal formların ve minimalist heykeltıraşların etkisi, 1970'lerin sonuna kadar tüm Avrupa'da, özellikle Hollanda ve İngiltere'de görülebilmektedir (Scarisbrick vd., 1989: 164-165). Takıya yansımaları ise formların rafine edilerek, aşır derecede sadeleştirilmesi olarak gözlemlenebilir.

1917 yılında Marcel Duchamp'ın 'Fountain' isimli eseriyle hazır nesneyi sanata dahil etmesi ve estetik beğeniyi ikinci plana atması, sanatın klasik kalıplarını kırmış ve sanatta kavram olgusunun habercisi olmuştur (Atakan, 
2008: 10). Modernizmle birlikte, sadece sanat alanında değil, tasarım disiplinlerinde de kavramsallık başlamış, eserin veya tasarım nesnesinin içeriği ile verdiği mesaj önem kazanmış ve bu gelişme sanat ve tasarımı birbirine yaklaştıran etken olmuştur.

\section{Takı Yapımına Yönelen Sanatçıların Etkisi}

Takıda yenilikçi anlayışın ortaya çıkması sürecinde, sanat alanındaki gelişmeler ve sosyal değişimin etkisi büyüktür. Duyarlı tasarımcıların üretimleri, farklı sanat disiplinleri arasındaki etkileşimler, takı olgusunun ve işlevlerinin sorgulanmaya başlanması, heykel, resim, grafik tasarımı gibi farklı sanat ve tasarım disiplinlerinde eser veren sanatçıların takı tasarlamaları ya da üretmeleri, yeni takı anlayışını var eden diğer etkenlerdendir.

1950'lerde, önemli ressam ve heykeltıraşların, sanatsal ifadenin yeni alanı olarak takı yapımına yöneldikleri bilinmektedir. Ancak hemen öncesinde, 1945 yılında heykeltıraş Henning Koppel'in Danimarkalı firma Georg Jensen için ilk gümüş takılarını oluşturduğu kaydedilmiştir (Phillips, 2000: 116). Koppel'in yalın, asimetrik formlu heykelsi takıları, takıda klasik İskandinav Stili olarak tanımlanacaktır. Takı üreten sanatçılar konusundaki ‘ilk’lerin, İsviçreli heykeltıraş Alberto Giacometti (Scarisbrick vd., 1989:150) ve en ünlü eserleri “Mobiller” olan Amerikalı heykeltıraş Alexander Calder olduğu, kaynaklarda yer almaktadır. Calder'in gümüş ve pirinç tellerden ürettiği takılar, 1930'lara tarihlenir (Schon, 2004: 20). Ernst, Cocteau, de Chirico, Man Ray, Tanguy ve Dubuffet küçük birer takı koleksiyonu oluşturan diğer sanatçılardır (Scarisbrick vd.,1989:150).

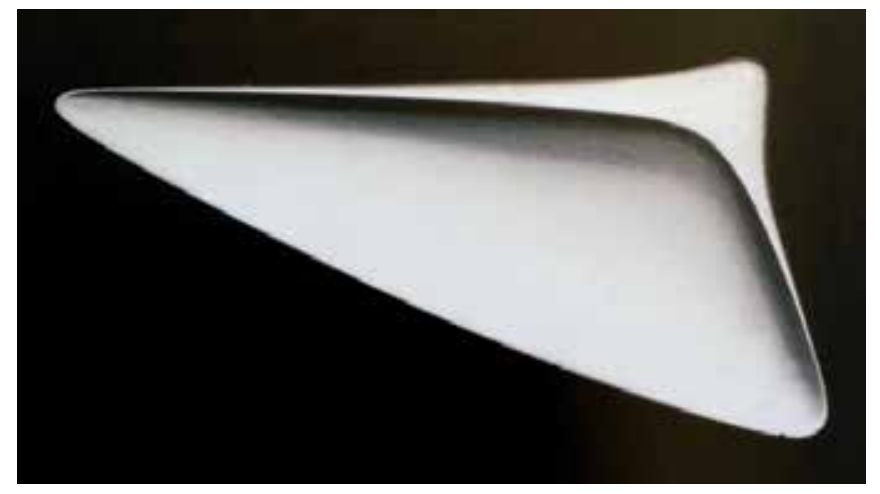

Resim 2. Henning Koppel, Jensen için üretilen broş.
Takı ve heykel arasındaki sınırların aşılması, sadece heykel veya resim üreten ya da bu eğitimi almış sanatçıların takı yapmalarıyla değil, aynı zamanda heykel ve/ veya resim sanatında kullanılan teknik ve malzemelerin takı yapımında da kullanılmasıyla mümkün olmuştur. Sözgelimi Amerikalı takı sanatçısı Sam Kramer, asamblaj heykel ve resim tekniğini kullanan sanatçıları taklit ederek, takılarına buluntu objeler (found objects) dahil etmeye başlamıştır (Scarisbrick vd.,1989: 151). Bu çalışmalar, takı ve heykel arasındaki bariyerin daha da çok aşınmasına sebep olmuştur.

1960'ların ilk yarısında Georges Braque, Paris'eki Museé des Arts Decoratifs'te sergilenen 130 parçadan fazla takı tasarlamıştır. Takı alanında daha çok ürün veren, İspanyol sürrealist Salvador Dali olmuş ve sürreel büyük bir koleksiyon oluşturmuştur. Bu ürünlerin çoğu takılabilir parçalar değildirler ancak Dali kendi çalışmalarının Benvenuto Cellini, Sandro Boticelli, ve Leonardo da Vinci geleneğinde olduğunu iddia etmiştir. İtalya'da ise Bruno Martinazzi, takı alanında eser veren ilk heykeltıraş olmuştur (Scarisbrick vd.,1989: 150).

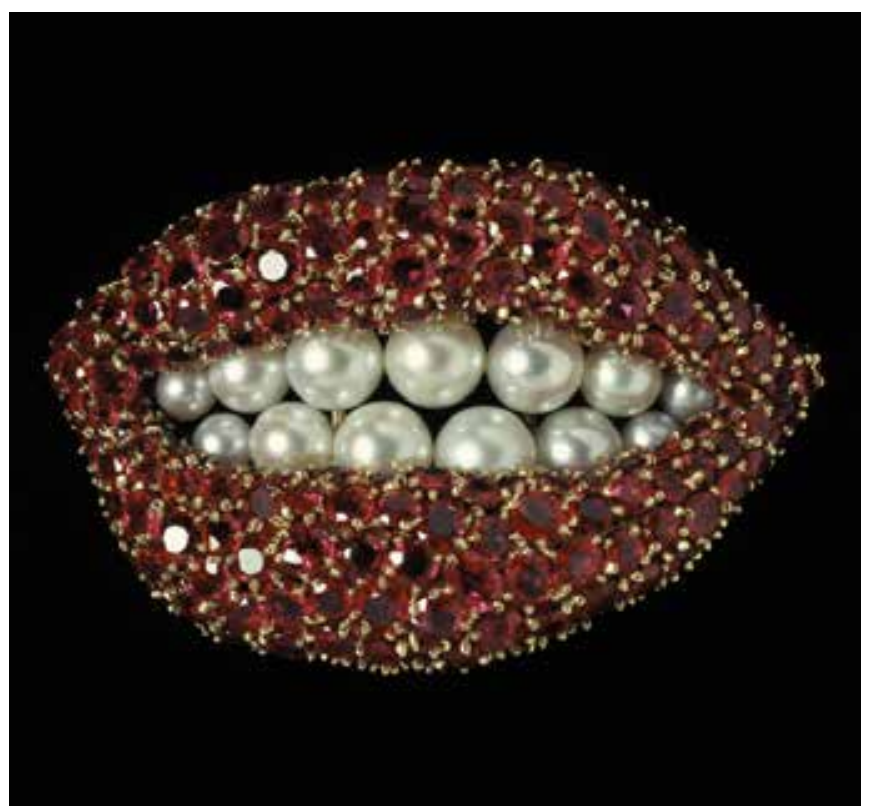

Resim 3. Salvador Dali, 'Ruby’s Lips’, 1946.

Farklı disiplinlerden gelen takı tasarım ve üretimiyle uğraşan sanatçıların bireysel sanat anlayışları seyirciye, ürettikleri takılar aracılığıyla yansımıştır. Böylece sanat- 
çılar, takının hem biçimsel hem de kavramsal olarak ifade ettiği değerlere farklı bir bakış açısı kazandırmışlardır. Dolayısıyla bu çalışmaların, takının bir sanat nesnesi olarak değerlendirilmeye başlanmasına katkısı büyüktür.

\section{Takının Gelişim Sürecinde 1960’ı Yıllar}

1960'larda sanatta zihinsel süreçlerin devreye girmesiyle, objede plastik değer aşılmıştır. Kavramsal boyutta nesnenin kendisi bir şey anlatmaktadır, estetik ikinci plana atılmıştır. Avangard tavır ve bireysel ifadenin birleşimi, takı alanında yeniliklerin ortaya çıkmasını sağlamıştır. Takının gelişim süreci içerisinde devrimsel nitelikte en büyük kırılmanın yaşandığı dönem, 1960 ’lı yıllar olarak bilinir. Bu yıllarda "takının heykele, giysiye ve hatta performans sanatına yaklaştığı sınırlar araştırılmış ve takı, basit bir süslenme elemanı olmaktan ziyade, sanatsal denemelerin ortamı haline gelmiştir." (Phillips, 1996: 195).

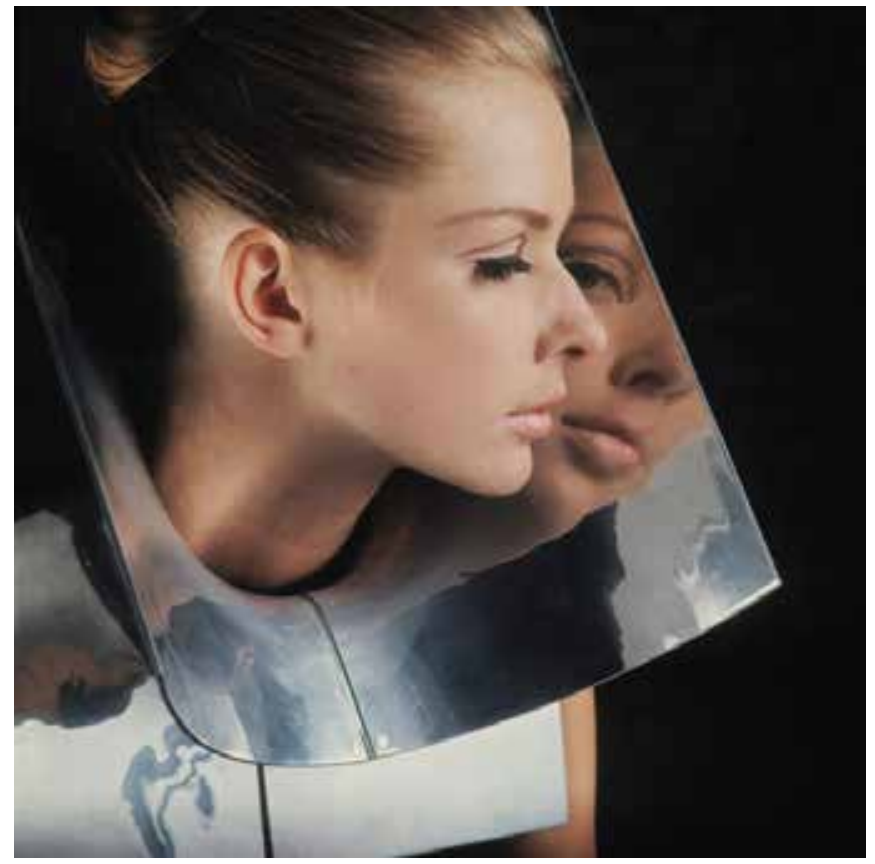

Resim 4. Gijs Bakker, 'Large Collar'.

Geleneksel yöntemlerin kullanıldığı takı ve mücevher üretimi ve kullanımı devam ederken, Gijs Bakker ve Emmy Van Leersum gibi öncü takı tasarımcılarının çalışmaları 'yeni takı' olarak adlandırılan ayrı bir kategori oluşturur. Geleneksel tasarım eğitimi almış bu öncü tasarımcılar, basit formlar kullanarak deneysel takılar üretmişlerdir. 1960'lı yıllarda ürettikleri ve kullanıcısını fiziksel olarak kısıtlayan büyük boyun takıları, Avrupa'da ve Amerika'da diğer takı yapımcılarını da etkilemiştir (Scarisbrick vd., 1989: 166). Ayrıca Gijs Bakker, 1960'ların sonundan itibaren sentetik ve değerli olmayan malzemelerle deneysel takılar yapan ilk tasarımcılardandır (Phillips, 2000: 122). Takının bu tarihlere kadarki ana malzemesini oluşturan değerli metallerin kullanımını reddederek, deneysel form ve yöntemlerle üretilen yeni takılar, takı kavramının sorgulanmaya başlanmasına neden olmuştur. 1960'larda değerli metallerle oluşturduğu soyut kompozisyonlarla takıya yeni yaklaşımlar kazandıran Alman Hermann Jünger, eğitimci yönüyle de önemli bir sanatçıdır (Phillips, 1996: 211). Öncü takı sanatçı ve tasarımcılarının sıra dışı çalışmaları, 'takının, ne zaman takılmaz hale geldiği, ne zaman heykele dönüştüğüne' ilişkin soruların oluşmasına sebep olur. Bu sorgulama, 15- 20 yıl kadar devam eder (Scarisbrick vd.,1989: 166).

Almanya'da yeni tarz çalışmaların yapılması, 1961 yılında Pforzheim'da Schmuckmuseum'un (Takı Müzesi) açılışıyla teşvik edilmiş̧tir. Londra'da aynı yıl Goldsmiths Hall, 28 ülkeden gelen 1000'in üzerinde sergi objesine, yeni takıyı da dahil etmiştir ve bu, yeni takının dahil olduğu ilk ciddi sergi olarak kayda geçmiştir (Phillips, 1996: 195). Bu dönemin sonunda sanatsal obje olarak takılar, müze ve galerilerde yerlerini almaya başlamışlardır.

\section{Geleneğin Aşılması ve Sanatsal Takılar}

1960'larda ortaya çıkan yeni takı anlayışı, o tarihe kadar tasarlanıp üretilen takının geleneklerinden kopmasını sağlamıştır. Takı kavramında yaşanan değiş̧im, alışılagelmiş takı kriterlerinde de büyük dönüşümlere neden olmuştur. Takıda uyulması gereken malzeme, boyut, ergonomi gibi tasarım kriterleri, geleneksel anlayışla üretilen takılarda kısıtlayıcı birer unsur olmayı sürdürürken; sanatsal ifadenin ön planda olduğu takılarda bu kriterler göz ardı edilebilmektedir. Sanatçı, tasarım kriterlerine göre üretmeyebilir ve ortaya çıkan çalışmalar da algı ve konvansiyonlara meydan okur nitelikte olabilir.

Yeni malzeme ve teknikler deneyimlemeye teşvik edil- 


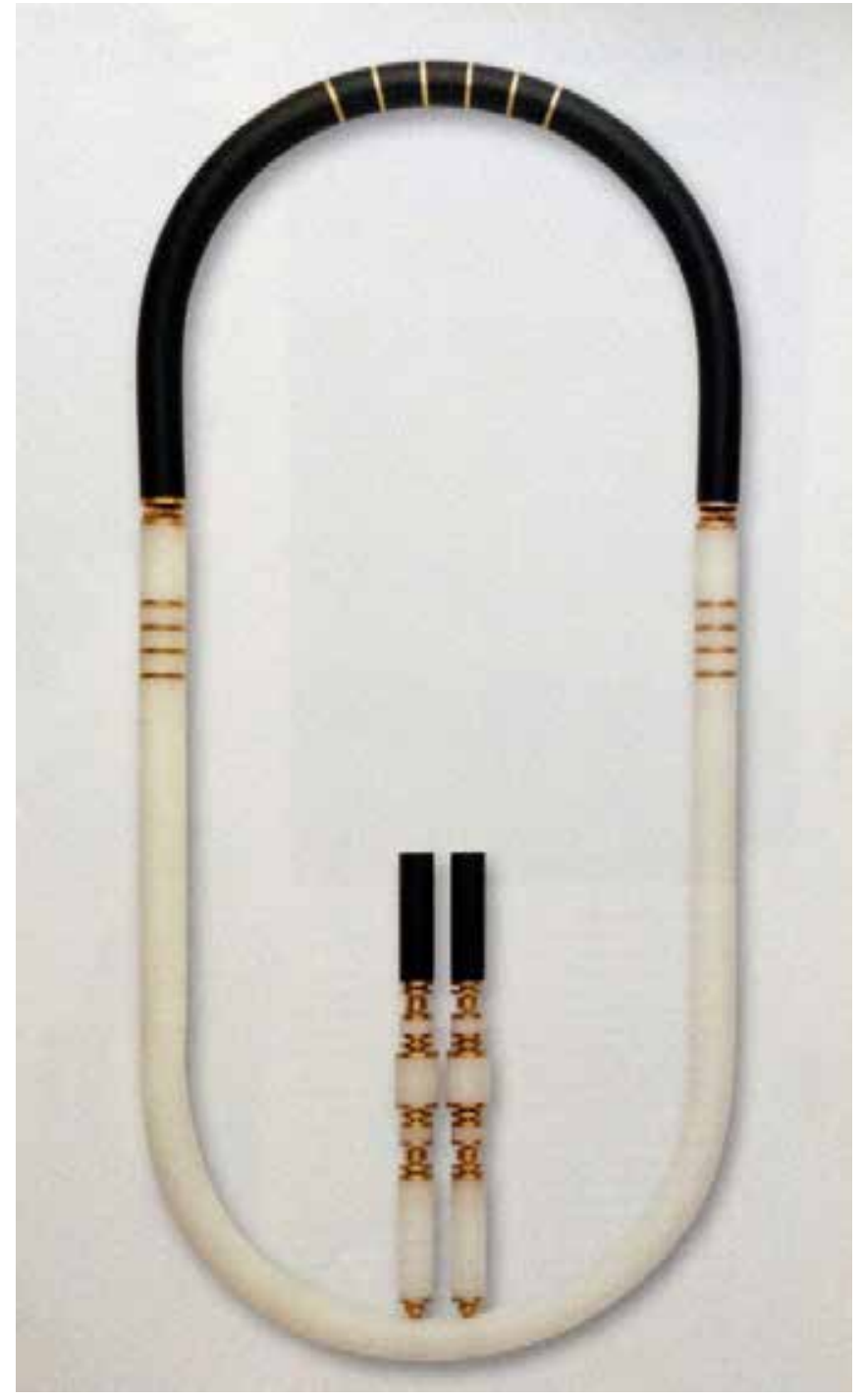

Resim 5. David Watkins, altın disk parçalarla süslenmiş akrilik boyun takısı, 1975.

dikleri bir sanat eğitimi almış ve farklı form ve malzeme arayışında olan yeni nesil takı sanatçı ve tasarımcılarının gündeme getirdiği deneysellik, takıda yeni bir bakış açısının edinilmesini sağlamıştır. Tasarımcı ve sanatçıların sosyal değişimlere duyarlılıklarıyla birlikte yenilikçi vizyonları da çalışmalarına yansımıştır. Tüm bunların yanında sanat alanındaki zihinsel değişimin sanat disiplinleriyle beraber takıyı da etkisi altına alması ve bunun sonucunda kavramsal takıya yönelim, sanat ve takı kavramlarını bir araya getiren etken olmuştur.

Takı kavramı değiştikçe, takı formunun alışılandan uzaklaştığı ve boyutlarının farklılaştığı gözlemlenir. Takı üretiminde sadece değerli madenin kullanılması gerektiği fikri, İkinci Dünya Savaşı sonrasında sanat eğitimi veren kurumlarda deneyselliğin desteklenmesiyle birlikte ortadan kalkmış ve takı yapımında alternatif malzemeleri gündeme getirmiştir. Sahne takılarında imitasyon malzemelerin kullanılmasıyla başlayan süreç, günümüzde 'güzel' anlayışının yeniden sorgulanmasına yol açacak kadar takıya ait olabileceği dahi düşünülmeyen malzemelerin kullanımına varmıştır.

Radikal takı sanatçıları arasında yer alan İsviçre doğumlu Otto Künzli, Hermann Jünger'in öğrencisidir ve çalışmalarıyla en çok tartışma yaratan isimlerden biri olmuştur (Phillips, 1996: 197). 1980'lerin başında duvar kağıdıyla kaplanmış büyük köpük bloklardan yaptığı broşlar, takının beklenen form ve fonksiyonundan ne kadar uzaklaşabileceğini göstermiş ve ürettiği bu takıların, 'hala takı olarak tanımlanabileceği' konusunun tartışılmasına neden olmuştur. Zenginliğin teşhirinden ve takı aracılığıyla gösterilmesinden rahatsızlık duyan sanatçı, 'Cold makes you blind' (altın sizi kör eder) isimli bileziğinde, gerçek altından bir topu, siyah bir lastik bandın içinde tamamen saklayarak kullanmıştır (Phillips, 1996: 198).

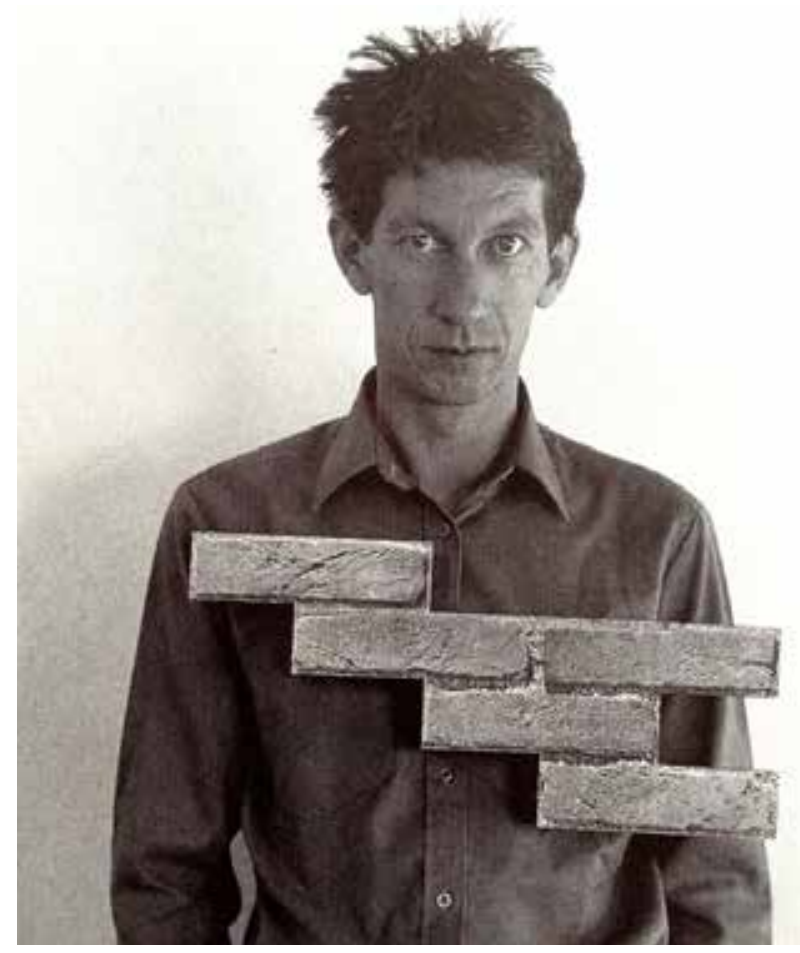

Resim 6. Otto Künzli, sert köpükten yapılarak desenli duvar kağıdıyla kaplanmış broş, 1983 
1970'lerde çoğu İngiliz tasarımcının da, takı yapımında alternatif sayılabilecek malzemeleri kullanmak üzere değerli metalleri terk ettikleri, kaynaklarda yer almaktadır (Scarisbrick vd.,1989: 173). Bu konuda örnek oluşturabilecek İngiliz öncü takı sanatçılarından Wendy Ramshaw, değerli metallerin yanında, kağıt, cam, porselen gibi malzemelerle denemeler yapmıştır (Scarisbrick vd., 1989: 177). Denemeler yapılan diğer malzemeler arasında; akrilik, plastik, alüminyum, çelik, lastik, kağıt gibi kuyumculukta o döneme kadar kullanılmamış malzemeler yer almaktadır. Malzemenin kağıttan reçineye kadar çeşitlenmesi, takı dünyasına sayısız varyasyon getirmiştir (Scarisbrick vd.,1989: 167).

Malzemenin çeşitlenmesinin yanı sıra yeni takıların ergonomisinde de önemli değişiklikler görülür. Takıda, insan vücudunu esas alan ergonomi ve takılabilirlik, önemli geleneksel tasarım kriterlerindendir. Kullanıcı, fiziksel olarak takıyla ilişkilidir ve takıyı taşımada aktif rol oynar. İnsan vücudu, takıya özel sergi alanı veya takıların üzerinde sergilendiği taşınabilir bir galeri olarak yorumlanmıştır. Takı, vücudun hareketinden etkilenir veya yeni takılarda olduğu gibi vücudun hareketini etkiler (Lewin,1994: 59). Bu nedenle takı, geleneksel olarak, ergonomi kriterlerine göre tasarlanmalıdır ve bunu yaparken, antropometrik ölçütler de göz önünde bulundurulmalıdır. Obje- kullanıcı ilişkisi esastır. Ergonomi kriterlerini aşarak, takılabilirliğin sınırlarını zorlamasıyla ürettiği çalışmaların takılması 'happening' olarak yorumlanan (Ilse-Neuman,2009: 17) İngiliz takı sanatçısı Suzannah Heron, bu yaklaşımıyla dönemin takı sanatçılarına ilham kaynağı olmuştur.

Takı, kelime anlamı doğrultusunda bir fonksiyon beklentisi yaratmaktadır. Mimar Sullivan’a göre "biçim, fonksiyonu takip eder" yani bir obje, kendisinden beklenen fonksiyona göre şekillendirilmektedir. Takı özelinde bu, vücut üzerinde yerleştirileceği alanının tariflenmesiyle ortaya çıkar. Sözgelimi, yüzüğün parmağa geçirilebilmesi için, yüzeyinde dairesel bir delik bulunması beklenmektedir. Yüzük formu, fonksiyonuna yönelik olarak deliklidir. Ancak, 'bir parçanın fonksiyonunun ne olacağını gösteren unsur genelde heykelsi takılarda daha az bellidir' (Olver, 2004: 151).

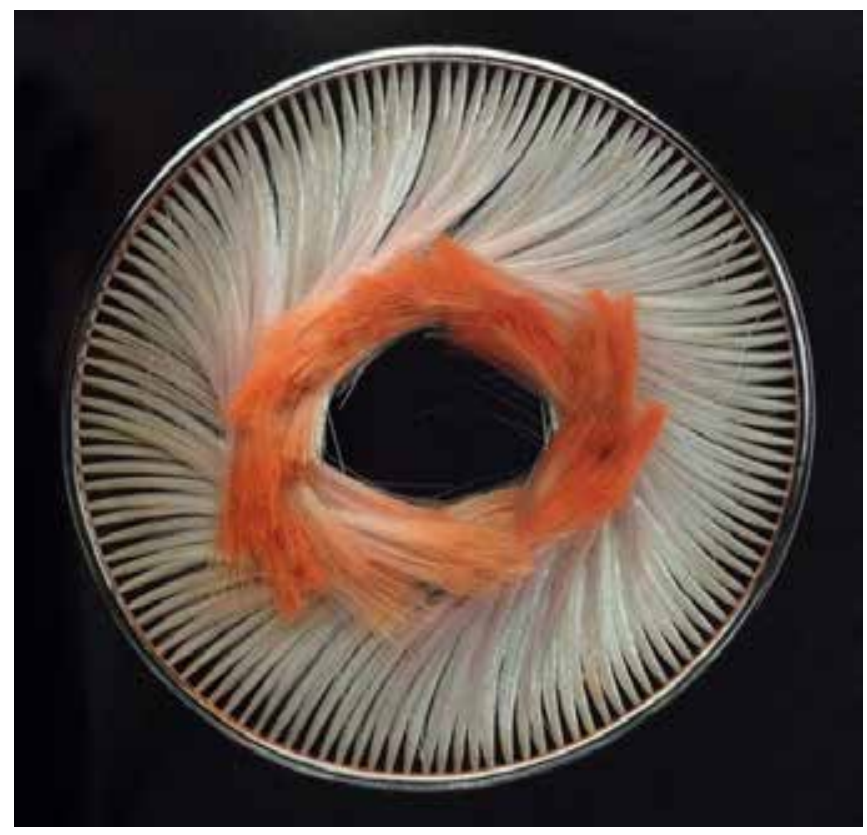

Resim 7. Marjorie Shick, 'Ring of Fire', boyun takısı, 1995.

“Modern sanatçıların çoğu fonksiyon fikrine direnmişler, işe yarama ve estetik özgürlük, iki farklı uç olarak görülmüştür. Sanki takının vücuda takılması esaret veya sınırlandırılmanın bir formuymuş gibi, çoğu sanatçı, sanat panteonuna girebilmesi için takının fonksiyondan sakınması gerektiğini beyan etmiştir." (Lewin,1994: 12). Fonksiyonellik, sanatsal takıyı tam anlamıyla değerlendirmenin sadece bir kısmını oluşturabilir. Sanatsal ifade aracı olarak tasarlanan ve üretilen takılarda, fonksiyon beklentisi ikinci planda kalmaktadır. Çünkü bu takılarda formun baştanbaşa bütünlük sağlaması ya da sanatçının tasarladığı etkiyi izleyiciye yansıtabilmesi esastır.

\section{Takıda Heykel Sanatının Etkisi ve Takının Heykelsileşmesi}

Güzel sanatlardaki gelişmeler, takı alanında giderek artan yansımalar bulmuş ve takının önceden tanımlanmış formundaki dönüşüm, takıyı yepyeni bir noktaya taşımıştır. Heykel sanatının tipik öğeleri olan kütle, biçim ve denge kavramlarının artık sadece heykel sanatını ilgilendirmemesi, bu iki farklı disiplini, ortak noktalarda birleştirmiştir. Takının nesne olarak üç boyutlu olan doğası ve modern 
takı alanında yaratılan formların heykel sanatının kaygılarıyla beslenmesi, takıyı heykel sanatıyla ortak paydada buluşturmuştur. Diğer takı türlerinde de olduğu gibi heykelsi çalışmalar da; biçim, renk, doku, duygusal etki, fonksiyon ve konsept olgularının tümü (Olver, 2004: 151) göz önünde bulundurularak dikkatlice tasarlanmalıdır.

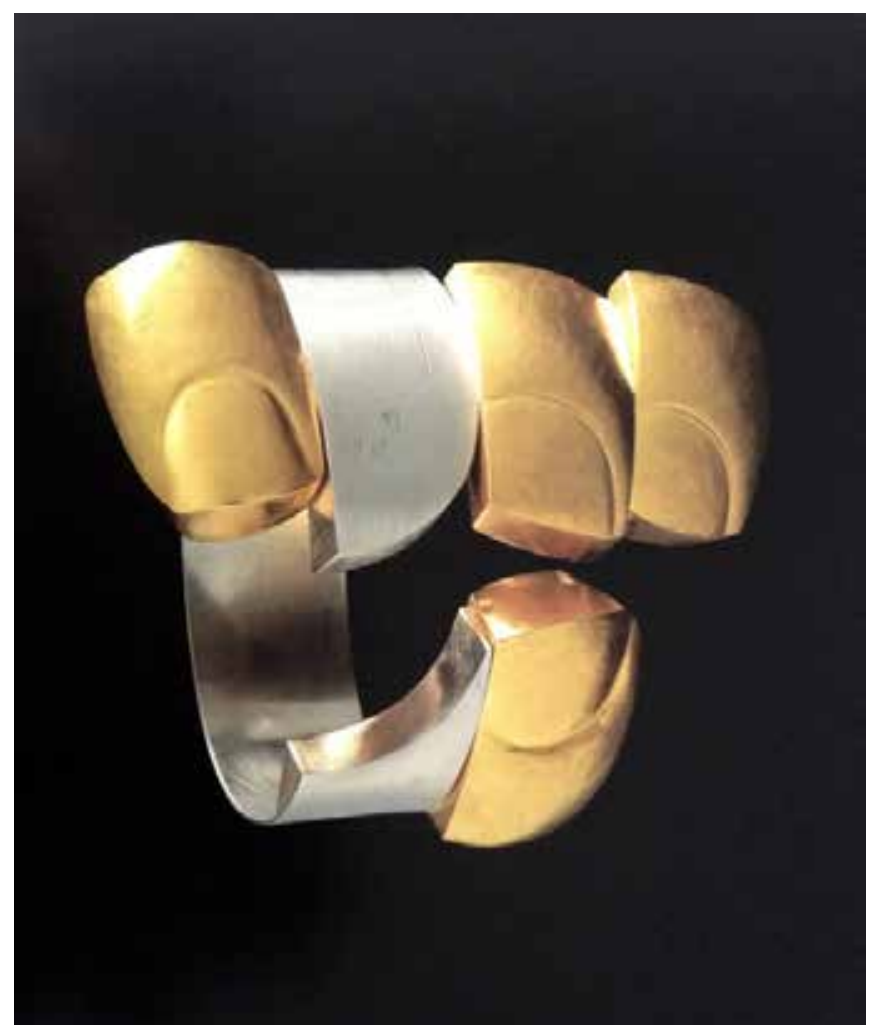

Resim 8. Bruno Martinazzi, 'Metamorfosi’, altın bilezik, 1992.

Takı sanatçısı ve heykeltıraş aynı zengin kültürel mirastan beslenirler ve benzer malzeme sorunlarıla başa çıkarlar. Her iki disiplinde de, konvansiyonel teknik ve malzemelerin dışına çıkıldığı görülmektedir. Sanatsal takılara bakıldığında, aktarılmak istenen fikrin nesnel uygulamasında da, modern heykel unsurları gözlenmektedir. Geleneksel ve güncel malzeme ve teknikler yer yer kombine edilmiştir. Tıpkı bir heykelde olduğu gibi türünün tek örneği olarak üretilen sanatsal takılarda, kısıtlamalar ortadan kalkmıştır. Kullanılan malzeme ve üretim yöntemleri de takı ve heykel alanlarını birbirine yaklaştırmıştır. Bu yakınlığın kanıtı, paylaştıkları pek çok kaygıda mevcuttur. 1960'larda ortaya çıkan yeni takı anlayışı kapsamında 'formun dengeli kullanımı' ve 'kütlenin boşlukta kapladığı alan' gibi, aslen heykel sanatına ait olmuş kaygılar, takının heykelsi yönünü ortaya çıkartmıştır (Ilse-Neuman, 2009: 11). Bu dönemde ve sonrasında yaratılan sanatsal takıların, form açısından oldukça dengeli oldukları görülmektedir. Bunlar, 'heykelsi takılar' (sculptural jewellery) olarak da tanımlanabilmektedirler.

Sadece bir moda aksesuarı değil, artık bir sanat formu da olan takı, küçük ölçekli heykel olarak da yorumlanabilmiştir. Bu bağlamda yaratılan bazı takıların, vücuttan bağımsız olarak da heykel gibi bir obje olarak varlıklarını sürdürdükleri dikkat çeken özellikleridir. Olver'e göre (2004: 151) takı, vücut üzerinde olduğu kadar, takılmadığı zamanda da bir ifade biçimi olmalıdır. Sanatsal takı, antropometrik ölçütlere uyarlanan bir heykelin fonksiyon kazandırılmış hali olarak da algılanabilir.

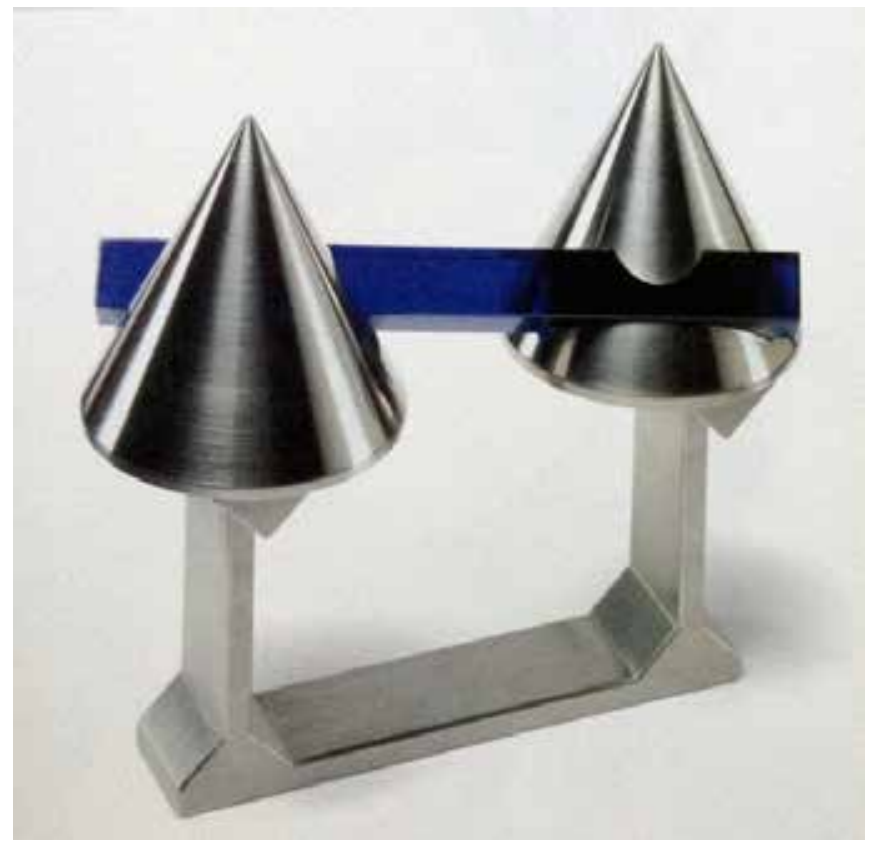

Resim 9. Friedrich Becker, sentetik safirli çelik bilezik, 1988.

1960'larda ve 1970'lerin başında takının heykel sanatından etkilendiğinin işareti, öncü takı sanatçılarının veya sergi düzenleyen kurumların takı sergilerine verdikleri isimlerdir. Sözgelimi takı kavramının sorgulanmasına yol açan tasarımcılardan Emmy Van Leersum ve Gijs Bakker'ın 1966-67 yillarında Amsterdam ve Londra'da 
açtıkları, diğer bir yandan ismiyle yeni nesil takı sanatçılarının takıya bakışlarını yansıtan 'Sculpture to Wear' (Giymek/ Takmak için Heykel) (Philips, 1996: 195-196) adlı ortak sergi dikkat çekicidir. Aynı şekilde, 1973 yılında, Boston'da yer alan The Institude of Contemporary Art'ın (ICA) 'Jewelry as Sculpture as Jewelry' (Takı Olarak Heykel Olarak Takı) sergisi de takı ve heykel arasındaki sınırların yok olmaya başladığını açık bir biçimde göstermektedir. Bu sergide Cara Lee Croninger, Pablo Picasso, Georges Braque, Roy Lichtenstein, Man Ray gibi isimler, takı tasarımlarıyla yer almışlardır (Lewin, 1994: 51).

\section{Sonuç}

20. yüzyılın hızıı gelişmelerinden sonra takı adına bir değerlendirme yapmak gerekirse, esas olanın sanatçının takı yoluyla kendini ifade etmesi olduğu gözlemlenir. Sanat ve tasarım anlayışları arasındaki ayrımın netliğini kaybettiği bu yıllarda, bir nesnenin sanat eseri mi yoksa tasarım objesi mi olduğu tartışmalara yol açmıştır. Üretilen çaıışmanın kendisini sınıflandırmak her geçen gün daha da zorlaşmaktadır ve çoğu çalışma, tek bir başlık altında yer alamamaktadır.

'Sanatsal takılar' olarak kategorize edilebilecek çaıışmalar, yapımında kullanılan malzemelerin değerinden kaynaklanan pahaları veya işçiliklerinin geleneğe uygun olmasından ziyade; fikir, yaratıcılık ve içerikleriyle değerlendirilmelidirler. Sanatsal takı, takı yapımına yönelen sanatçıların kendilerini ifade etmeyi seçtikleri alandır. Sanatsal takıda fikir esas olduğundan, diğer takı olma kriterlerinin arka planda yer aldığı gözlenir. Bu bağlamda, sanatsal bir ifade yöntemi olarak ortaya konan takı ele alındığında, gelişim süreci içerisinde ve günümüzde dahi heykel sanatından etkilense de, esas olan takı sanatçısının kendini ifade edeceği yöntemi bulmasıdır. Sanatta disiplinlerarası geçişler mevcuttur ve sanat eserinde farklı sanat dallarına ait yöntemlerden yararlanılması sanatçının izleyiciyle iletişim kurmasında büyük rol oynamaktadır. Sanatsal takı, ilk planda sanat eseri olarak tasarlanıp üretilmektedir ve sanatçının izleyiciye vermek istediği mesaj ya da takı aracılı̆̆ıyla yaşatmayı amaçladığı de- neyim esastır. Bir bakıma üretilen çalışmalar, güçlü kavramlar içeren çağdaş objeler halini almışlardır. Sanatsal tavır olarak ortaya konmuşlardır ve artık yeni bir sanatsal ifade biçimleridirler. 20. yüzyılda takı sanatçılarının yeni ifade yöntemi haline gelen takı, 1960'larda olduğu kadar dramatik olmasa da, günümüzde hala sanatsal gelişimini sürdürmektedir

\section{Kaynakça}

Astfalck, I., Broadhead, C., Derrez, P. (2005). New Directions in Jewellery, London: Black Dog Publishing Limited.

Atakan, Nancy (2008). Sanatta Alternatif Arayışlar, Izmir: Karakalem Kitabevi Yayınları.

Ilse-Neuman, Ursula (2009). Inspired Jewelry From the Museum of Arts and Design, UK: ACC Editions/ Antique Collector's Club Ltd.

Lewin, Suzan Grant (1994). One of a Kind, American Art Jewellery Today, New York: Harry N. Abrams, Inc., Publishers.

Olver, Liz (2004). The Art of Jewelry Design, from Idea to Reality, London: A\&C Black Publishers Limited.

Phillips, Clare (1996). Jewelry, From Antiquity to the Present, London: Thames and Hudson LTD.

Phillips, Clare (2000). Jewels and Jewellery, London: V\&A Publications.

Scarisbrick, D., Ogden, J., Lightbown, R., Hinks, P., Bayer, P., Becker, V., Craven, H. (1989). Jewellery, Makers, Motifs, History, Techniques, London: Thames and Hudson Limited.

Schon, Marbeth (2004). Modernist Jewelry 1930-1960 The Wearable Art Movement, PA: Schiffer Publishing Ltd.

\section{Görsel Kaynaklar}

Resim 1. Alexander Calder, 'The Jealous Husband', pirinç kolye https://www.flickr.com/photos/artimageslibrary/ 5004589420/ (Erişim tarihi: 11.04.2015)

Resim 2. Henning Koppel, Jensen için üretilen broş. (Phillips, 2000: 116). 
Resim 3. Salvador Dali, 'Ruby's Lips', 1946 http://artblart.com/tag/salvador-dali-rubys-lips/ (Erişim tarihi: 20.04.2015)

Resim 4. Gijs Bakker, 'Large Collar' http://www.stedelijk.nl/en/press/press-images/thegijsemmy-spectacle (Erişim tarihi: 22.04.2015)

Resim 5. David Watkins, altın disk parçalarla süslenmiş akrilik boyun takısı, 1975. (Phillips, 2000:127).

Resim 6. Otto Künzli, sert köpükten yapılarak desenli duvar kağıdıyla kaplanmış broş, 1983 (Phillips, 1996: 197).

Resim 7. Marjorie Shick, 'Ring of Fire', boyun takısı, 1995 (IlseNeuman, 2009: 79).

Resim 8. Bruno Martinazzi, 'Metamorfosi', altın bilezik, 1992 (IlseNeuman, 2009: 141).

Resim 9. Friedrich Becker, sentetik safirli çelik bilezik, 1988 (Phillips, 2000: 131). 